JPH: Jurnal Pembaharuan Hukum

Volume 8, Number 1, April 2021

\title{
CORPORATE CRIMINAL LIABILITY FOR CRIMINAL ACTS OF CORRUPTION
}

\author{
Muhammad Ridwan Lubis \\ Muslim Nusantara University Al-washliyah \\ muhammadridwanlubis76@gmail.com \\ Panca Sarjana Putra \\ Islamic University of North Sumatra \\ panca.sh2601@gmail.com \\ Yasmirah Mandasari Saragih \\ Panca Budi University \\ yasmirahmandasari@gmail.com
}

\begin{abstract}
The practice of this criminal act of corruption that involves corporations is an extraordinary crime and is very detrimental to the state. The direct consequences of these crimes to society are financial losses, job losses, and even loss of life due to the crisis. Researchers use normative juridical research methods with 3 (three) approaches to examine two problems discussed with normative research methods. It was found that corporate crime against corruption contained five theories of strict liability according to the law (strict liability) where historically the law began to pay more attention and the principle of absolute responsibility as a punishment needed to prevent retaliation then changed. be a responsibility based on the element of error
\end{abstract}

Keywords: Corporate Criminal; Corruption; Criminal Liability;

\section{A. INTRODUCING}

Indonesia was idealized and aspired by the founders of the state as a rule of law (Rechtsstaat). The 1945 Constitution Article 1 paragraph (3) states that "Negara Indonesia adalah Negara Hukum". ${ }^{1}$ The Indonesian nation has a noble legal instrument as the foundation of national and state life, namely Pancasila and the 1945 Constitution. The consequence of making Pancasila as the basis of the nation's philosophy means that in every life of the nation and state, Pancasila must be the basis that animates every step of development including the development of the Indonesian National Law System, both the development of legal substance, legal structure and legal culture. ${ }^{2}$

1 Bambang Tri Bawono, The Strategy For Handling Corruption's Criminal Action Relationship To Saving Of State Financial Losses, Jurnal Pembaharuan Hukum, Vol 7, No 3, December 2020, page.222-231

2 Sri Endah Wahyuningsih Urgensi Pembaharuan Hukum Pidana Materiel Indonesia Berdasarkan Nilai-Nilai Ketuhanan Yang Maha Esa, Jurnal Pembaharuan Hukum, Vol I No.1 Januari-April 2014, page.17-23 
Until now, the Indonesian nation is intensively carrying out a major mission that falls into the category of major crimes (Extra Ordinary Crimes) so that it can support the creation of National development goals, namely creating a just and prosperous society based on the mandate of Pancasila and the supreme constitution of the 1945 Constitution. ${ }^{3}$

Talking about corruption is actually not a new problem in Indonesia. In fact, various groups consider that corruption has become a part of life, become a system and is integrated with the administration of state governance. There are still many failures in overcoming corruption by using existing statutory instruments. This situation will shake democracy as the main foundation in the life of the nation and state, paralyze the values of justice and legal certainty and further away from the goal of achieving a prosperous society. ${ }^{4}$

The very old historical roots of corruption make it difficult to eradicate, let alone eradicate, as difficult as eradicating other crimes such as robbery and theft, perhaps what can be done is to minimize and limit the space and opportunities for corruption to occur with anticipatory (premtive) measures and law enforcement. consistent (repressive). In developed countries that are known to have good governance and clean, corruption cases are often found on a small or large scale (petty and grand corruption). ${ }^{5}$

Over time, the practice of corruption, which is increasingly prevalent and diverse, does not only involve a handful of people or certain groups, but state officials, state administrators, or the bureaucracy within the government. Some of these corruption practices also involve corporations. Where the corporation is one form of activity organization, which mainly has business activities. At the beginning of its development, a corporation is an organization or business entity that aims to obtain benefits for its owners, with various risks that are also borne by the owner of the corporation.

The goal of the corporation to continue to increase the profits it receives results in frequent violations of the law. A corporation, whether in the form of a legal entity or not, has great power in carrying out its activities so that it often carries out activities that are contrary to applicable legal provisions, even causing victims to suffer losses. However, many corporations have escaped the pursuit of the law so that corporate actions that are against the law are increasingly widespread and difficult to control. Corporations with ease in eliminating evidence of crimes against society, including intervening law enforcement officials. ${ }^{6}$

3 Marwan Effendy, Pemberantasan Korupsi dan Good Governance, PT. Timpani Publishing, Jakarta, 2010, page. 1

4 Suratno, Perlindungan Hukum Saksi Dan Korban Sebagai Whistleblower Dan Justice Collaborators Pada Pengungkapan Kasus Korupsi Berbasis Nilai Keadilan, Jurnal Pembaharuan Hukum, Volume 4 No. 1 Januari-April 2017, page.130-139

5 Mustaghfirin, Irwanto Efendi, Tinjauan Yuridis Terhadap Implementasi Pidana Korupsi Dalam Upaya Mengembalikan Kerugian Keuangan Negara, Jurnal Pembaharuan Hukum, Volume 2 No. 1 Januari-April 2015, page.11-22

6 Taun, Pertanggungjawaban Pidana Korporasi Dalam Tindak Pidana Ketenagakerjaan, Jurnal IUS, Vol VI, No 2 Agustus 2018, page, 236-244 
The position of corporations as one of the backbone of a country's economy tends to expand its wings in the business world to participate in various types of tenders held by the government as a source of profit. With this open opportunity, in its business activities, they take actions that can be detrimental. public interest, which is often known as corporate crime.

Indonesia recognized corporations as subjects of criminal law starting in 1951, namely since the enactment of the Law on hoarding goods which was later known more widely in Law Number 7 of 1955 concerning Economic Crimes. ${ }^{7}$ Initially, Indonesian criminal law only recognized people as criminal law subjects. This is as regulated in the Criminal Code which only recognizes human (natural person) as the perpetrator of a criminal act. The reason that corporations are not known as criminal offenders at this stage is because of the very strong influence on the non-potest societes deliquere principle, namely that legal entities cannot commit criminal acts or the university deliquere non-potest principle, which means that legal entities (corporations) cannot be convicted. ${ }^{8}$ The juridical provisions regarding corporations as legal subjects for criminal offenders in Wetboek Van Strafrecht (hereinafter referred to as WvS) in the Netherlands were stipulated on June 23, 1976 that corporations were formulated into article 51 of the Dutch Criminal Code.

The law is then followed by other laws such as, Law No. 71955 on Economic Crimes, Law No. 5 of 1984 on Industry, Law No. 6 of 1984 on Post, Law No. 9 of 1985 on Fisheries as amended by Law No. 31 of 2004, Law No. 7 of 1992 on Banking as amended by Law No. 10 of 1998, Law No. 8 of 1995 on the Capital Market, Law No. 10 of 1995 on Customs, Law No. 5 of 1997 on Psychotropics, Law No. 22 of 1997 on Narcotics, Law No. 23 of 1997 on Environmental Management, Law No. 5 of 1999 on the Prohibition of Monopolies and Unfair Business Competition, Law No. 8 of 1999 on Consumer Protection, Law No. 31 of 1999 on the Eradication of Corruption Crimes as amended by Law No. 20 of 2001, Law No. 15 of 2002 on Money Laundering Crimes as amended by Law No. 25 of 2003. ${ }^{9}$

The law turns out to take a different stance from the Criminal Code. These various laws stipulate that corporations can also be prosecuted as perpetrators of criminal acts other than corporate managers who carry out these acts for and on behalf of the corporation. This system is in line with the development of the corporation as a subject of criminal law phase I. Where the drafters of the Criminal Code still accept the principle of "non potest societas / university delinquere". This principle actually applies in the past century to all of continental Europe. This is in line with the opinions of

7 Widyo Pramono, Pertanggungjawaban Pidana Korporasi Hak Cipta, PT Alumni, Bandung, 2013, page. 2

8 Muladi dan Dwidja Priyatno, Pertanggungjawaban Pidana Korporasi, Kencana Prenada Media Group, Jakarta, 2010, page.86

9 Barda Nawawi Arief, Kapita Selekta Hukum Pidana, Citra Aditya Bakti, Bandung, 2003, page.223-226. 
individual criminal law from the classical school prevailing at that time and also from the modern school of criminal law. ${ }^{10}$

That the subject of the crime is in accordance with the explanation (MvT) of Article 59 of the Criminal Code, which reads: "a criminal act can only be committed by humans". Von Savigny once put forward a theory of fiction (fiction theory), in which corporations are legal subjects, but this is not recognized in criminal law, because the Dutch government at that time was not willing to adopt the teachings of civil law into criminal law. ${ }^{11}$

The purpose of writing in this study is to determine the responsibility of corporations as the subject of criminal acts in criminal acts of corruption so that legal certainty emerges in the enforcement of criminal law committed by corporations, which must be able to provide a deterrent effect for corporate actors who commit criminal acts, because seeing the wide impact can be caused by corporate crime for both the community, the economy and other aspects. Therefore, there must be consistency and cohesiveness for law enforcers to be able to impose criminal responsibility on corporations so that perpetrators of corporate crime are deterred from committing criminal acts.

\section{B. RESEARCH METHODS}

The researcher used a normative juridical research method with 3 (three) approaches to examine the two problems discussed by this normative research method, namely the legal approach and the conceptual approach. A statutory approach is needed to trace the legislative ratios and the ontological basis for the formation of legislation. ${ }^{12}$ The specification of this research is descriptive analysis, which is research that not only describes the state of the object but provides an overview of the problems that occur, especially regarding criminal liability in corporate crime against corruption. ${ }^{13}$

\section{RESULT AND DISCUSSION}

\section{The theory of corporate criminal liability against corruption}

The criminal act of corruption in Indonesia has been widespread in society in its development steadily increasing from year to year, both in terms of the number of cases that have occurred in the amount of state financial losses and in terms of the quality of criminal acts that have been increasingly systematic and the scope has penetrated all aspects of public life until criminal acts have increased. uncontrolled

10 Dwidja Priyatno, Kebijakan Legislasi Tentang Sistem Pertanggungjawaban Pidana Korporasi di Indonesia, CV Utomo, Bandung, 2004, page. 53.

11 Hamzah Hatrick, Asas Pertanggungjawaban Korporasi Dalam Hukum Pidana Indonesia (strictliability dan vicarious liability), Raja Grafindo Persada, Jakarta, 1996, page.30.

12 Peter Mahmud Marzuki, Penelitian Hukum, Kencana, Jakarta, 2014, page. 93-94

13 Ronny Hanitijo Soemitro, Metode Penelitian Prosedur Dan Strategi, Sinar Pagi, Jakarta, 1985, page. 9 
corruption will bring disaster not only to the life of the national economy, but also to the life of the nation and state in general. ${ }^{14}$

In the 20th century, debates about differences of opinion on corporate criminal responsibility occurred, according to Anca Iulia Pop in her writing on the theme Criminal Liability of Corporations-Comparative Jurisprudence, especially in the 1990s the United States and Europe experienced a number of major crimes involving various fields. Environment, anti-competition (antitrust), fraud (Fraund), food and drugs (food and drugs), foundation reports (bribery), violations of law enforcement (obstaction of justice), and crimes in the field of financial (financial crime) ${ }^{15}$

These crimes caused enormous losses, including corruption. The consequences that resulted directly from these crimes to society were financial losses, loss of jobs, and even loss of life as a result of the crisis. Therefore, there are several doctrines of corporate criminal responsibility against criminal acts of corruption. In corporate criminal liability itself has 5 fairly general doctrines of criminal responsibility, consisting of: ${ }^{16}$

a. Strict Liability Theory (absolute responsibility)

As one of the doctrines used as a basis for justifying the imposition of criminal responsibility on corporations. According to this theory, criminal responsibility can be borne by the perpetrator of a criminal act without having to prove the perpetrator's fault (intentional or negligent). This teaching is an exception to the application of the principle of actus nonfacit reum, nisi mens sit rea. Whereas the perpetrator of a criminal act can only be subject to a criminal burden if in committing the actus reus (behavior) as stipulated in the offense formulation, only if the actus reus committed by the perpetrator is motivated or based on mens rea (guilty conscience, intentionally or unintentionally) of the perpetrator. According to this theory, the public prosecutor is only obliged to prove actus reus regarding the causal relationship between actus reus and the consequences it causes.

b. Vicarious Liability Theory (liability replacement)

This teaching is criminal responsibility committed by one person to another. For example, a criminal act committed by the manager or a part of the management of a corporation, then the corporation itself is also liable. In this doctrine, the public prosecutor is obliged to prove mens rea as the basis for the perpetrator to commit actus reus. Actually, this doctrine or teaching is a teaching in civil law. However, it was later adopted by the criminal law to impose criminal liability on the corporation. This doctrine is usually applied in

14 Ermansjah Djaja, Meredesain Peradilan Tindak Pidana Korupsi (Implikasi Putusan Mahkamah Konstitusi Nomor 012-016-019/PPU-IV/2006, Sinar Gravika, Jakarta, 2010, page.129

15 Remy Sutan Sjahdeini, Ajaran Pemidanaan: Tindak Pidana Korporasi dan Seluk- beluknya, PT. fajar Interpramata, Jakarta, 2017, page. 21

16 Ibid, page. 150 
civil law concerning acts against the law (the law of torts) based on the superior doctrine of response. ${ }^{17}$

c. Doctrine of DelegationTheory

It is one of the bases that justifies the existence of criminal responsibility by the employees of the corporation. According to this doctrine, the reason why criminal liability can be imposed on corporations is because of the delegation of authority it has. A person who receives a delegation or delegation by the leadership of the board of directors of the corporation to be able to carry out an act on behalf of and in the interests of the corporation, then if a criminal act is found by the recipient, the corporation as the authoritative authority is responsible for it. The delegation of this delegation is essentially a power of attorney or the granting of a mandate according to the law, the act of the recipient of the power of attorney is binding on the power of attorney as long as it does not exceed his duties or powers.

d. Identification Theory

Identification theory is a teaching regarding the justification of corporate criminal responsibility, that in order to impose corporate criminal responsibility, the public prosecutor must be able to identify that the person carrying out actus reus is the controlling personnel of the corporation. This teaching was developed for the first time in England and then in the United States. Then many countries in the world adopt criminal responsibility for corporations. In essence, this theory originates in civil law theory regarding legal entities which determines that the management is an organizational organ. However, there are restrictions this principle can apply if:

1) Management in committing such actions does not go out of the way of the corporation's aims and objectives as stipulated in its Articles of Association;

2) The actions taken by the management must be in accordance with or within the limits of the management's authority as stipulated in the Articles of Association of the Corporation. In this case the action is classified as intra vires (in power) not ultra vires (out of power).

e. Corporate Organs Theory

It is a theory that refers to people who exercise authority and control in a legal entity, in other words the person who directs and is responsible for all actions of a legal entity, the person who sets corporate policies, and the person who is the brain of the corporation, which is an important organ of the company. corporation so that criminal responsibility can be asked.

Meanwhile, Sutan Remy Sjahdeini argued that the concept of corporate criminal responsibility was compiled from various teachings which he later referred to as the "Joint Teaching". Criminal liability

17 Remy Sutan Sjahdeini, Op.Cit., page. 33 
can be borne by the corporation and should fulfill certain elements, which include: ${ }^{18}$

1) Such behavior must constitute a criminal offense, either commission or omission.

2) Actsu reus (mistake) of the crime may be committed alone or ordered by the controlling personnel (controlling mind).

3) Mens rea of the crime rests with the controlling personnel of the corporation.

4) The criminal act must provide benefits to the corporation.

5) The crime is committed by exploiting the corporation, namely by involving the use of elements specifically related to the corporation, or only owned by the corporation.

6) The said crime is intra vires, that is, it is committed in the framework of the aims and objectives of the corporation as stipulated in the Articles of Association of the corporation.

7) Criminal acts committed by the controlling personnel of the corporation must be carried out in the framework of the duties and authorities of the legal controlling personnel according to corporate regulations or a letter of appointment.

8) If the actus reus (mistake) of the crime was not committed by the controlling personnel of the corporation but by someone else, the act must be based on orders, or the provision of power of attorney from the controlling personnel of the corporation or approved by the controlling personnel of the corporation.

9) The act must be an act that is against the law.

10)For criminal acts that require the existence of both elements of mens rea and actus reus, it does not have to be present in just one person but there can be several people separately.

According to Mardjono Reksodipuro there are at least three systems of corporate punishment, namely:

1) The management of the corporation, as a maker and manager, is responsible.

2) Corporations as makers and administrators are responsible.

3) Koporation as a maker and also as a responsible person.

Therefore, if a criminal act is committed by and intended for corporations, prosecution can be carried out and the penalty can be borne by the corporation, or the corporation and its management or management only. Besides this moral teaching, another factor that is also important in the process of changing attitudes is the perception of society that losses as a result of a "mistake" (negligenci) are not necessarily less important than losses resulting from deliberate

18 Syahdeini, Sutan Remy, Op. Cit., page. 197 
action. As for what is included in the definition of "error" is whether a deliberate act or moral negligence (moral responsibility) turns into a legal liability. ${ }^{19}$

In terms of the legal subject between the corporation and the controlling personnel of the corporation is a different subject, even though sometimes between the corporation and its controlling personnel as the same legal subject.

\section{Criminal Liability in Corporate Crime Against Corruption}

In terms of the mechanism for handling corporate cases is regulated in Perma no. 13 of 2016 concerning procedures for handling criminal acts by corporations, including corporations that commit criminal acts of corruption. Here it is seen that the urgency of eradicating criminal acts of corruption can be traced and eradicated even though it is covered by the guise of corporations in carrying it out. In this Perma Article 1 paragraph (8) explains that a criminal act by a corporation is a criminal act that can be held responsible for the corporation in accordance with the law that regulates corporate matters. In Article 2 the aims and objectives of the establishment of this Perma are aimed at :

a. To serve as a guideline for law enforcers in handling criminal cases with corporate actors and / or administrators.

b. Fill in the legal void, especially criminal procedural law with corporate actors and / or management and,

c. Encouraging the effectiveness and optimization of the handling of criminal cases with corporate actors and / or management.

The Supreme Court of the Republic of Indonesia regulates the procedures for handling criminal cases by corporations by issuing Supreme Court Regulation Number 13 of 2016 which further emphasizes that corporations can be held liable for crimes in accordance with the provisions in the law on corporations. Even though Indonesia has adopted a criminal liability system against corporations, until now there are still few corporations that have been named as suspects or defendants in the law enforcement process, especially in criminal acts of corruption. ${ }^{20}$

In the case of procedures for handling corporate cases, criminal responsibility can be asked in accordance with the provisions of corporate crime in the law regulating corporations, this is clearly stated in the Perma in Article 4 paragraph (1) and in imposing crimes against corporations in Article 4 paragraph (2) it explains The judge can judge the corporation's wrongdoing as referred to in paragraph (1), among others: (a) the corporation can obtain the benefits or benefits of the crime being committed for the benefit of the corporation (b) the corporation allows a crime to occur or (c) the corporation does not take the necessary steps to take precautions, prevent a greater impact and

19 Dwija Priyatno, Op.Cit, page. 107.

20 Hasbullah F.Sjawie, Pertanggungjawaban Pidana Korporasi Pada Tindak Pidana Korupsi, Prenada Media Group, Jakarta, 2015, page. 8 
ensure compliance with applicable legal provisions in order to avoid the occurrence of criminal acts. And when a person or more corporate management resigns, or dies, it does not result in loss of corporate responsibility, this is clearly regulated in Article 5.

The principle of non-punishment without guilt need not be too rigidly enforced in corporate responsibility considering the victimological aspects of coporation crimes that are so widespread. The rigid application of criminal liability for corporations can be a criminogenic factor that will increase the prevalence of corporate crime. ${ }^{21}$

Subjective requirements in criminal liability will include the ability to be responsible, deliberate / negligent and there is no excuse. If this will remain in use, then :

a. In criminal liability, the concept of functional behavior (daderschap) must be accepted. The distinctive feature of this functional behavior is that the physical act of one (who actually does) results in a functional act against the other. Thus, the responsible ability of people who act for and on behalf of the corporation is transferred to the capability of being responsible for the corporation as the subject of a criminal act.

b. The deliberate and negligent problem of the corporation can be covered in company politics or the actual activities of a company. It can also be explained by looking at the intention or negligence of the corporate management in company politics, or being in the real activities of a particular company. So the intentional or negligence of the corporation must be detected through the mental atmosphere prevailing in the corporation and by the management acting on behalf of the corporation.

c. Reasons for forgiveness for corporations remain valid by adopting reasons of forgiveness for natural persons. This is a consequence of the mistakes of the management acting for and on behalf of the corporation which are attributed to the mistakes of the corporation, so that the elimination of mistakes of the management for reasons of forgiveness also erases the mistakes of the corporation.

This Perma does not only regulate criminal liability for one corporation but also can ensnare corporate groups, corporations in mergers, consolidations, separations, and also in the case of corporations being dissolved and still subject to criminal charges against the corporation.

We can see the liability of the corporation in criminal acts of corruption in the formulation of article 20 of the law on corruption eradication at least 7 (seven) descriptions of the form of accountability, namely:

21 Rully Trie Prasetyo, Umar Ma'ruf, Anis Mashdurohatun, Tindak Pidana Korporasi Dalam Perspektif Kebijakan Formulasi Hukum Pidana, Jurnal Hukum Khaira Ummah, Vol. 12. No. 4 Desember 2017, page. 727-741 
a. In the event that a criminal act of corruption is committed by or on behalf of a corporation, charges and criminal charges can be made against the corporation and / or its management.

b. Corruption is committed by a corporation if the criminal act is committed by people either based on a work relationship or based on other relationships, acting within the corporate environment either individually or collectively.

c. In the event that criminal charges are committed against the corporation, the corporation continues to be represented by the management.

d. Managers who represent the corporation as meant in paragraph (3) can be represented by other people.

e. The judge may order the management of the corporation to appear before the court himself and may also order the management to be brought to trial.

f. In the event that a criminal charge is committed against a corporation, the summons to appear before and delivery of the summons shall be conveyed to the management at the management's residence or at the management's office.

g. The main punishment that can be imposed against a corporation is only a fine, provided that the maximum penalty is added by $1 / 3$ (one-third).

From the formulation of Article 20 of the Corruption Eradication Law above, at least it provides an illustration that the criminal act of corruption is committed by a corporation, if the criminal act is committed by people who are based on a work relationship or other relationship, acting within the corporate environment either individually or collectively same.

Thus, when a corporation is not sentenced to be responsible for the actions it has committed, it will have a significant impact, both for the corporation as an advantage, as well as a loss for the state in the future. By not imposing criminal responsibility on a corporation, law enforcers are deemed to be flawed because they do not carry out statutory regulations properly. ${ }^{22}$

\section{CONCLUSION}

Corporate crime against corruption includes five theories of strict liability according to the law (strict liability) where historically the law has begun to pay more attention to matters of an apologetic nature (execulpatory considerations), and as a result of the influence of "moral philosophy" from religious teachings, it tends to lead to the recognition of "moral culpability" as the proper basis for unlawful acts. So the principle of absolute responsibility as a punishment needed to avoid retaliation then turns into responsibility based on the element of "error". This regulation not

22 Ibsaini \& Mahdi Syahbandir, Pertanggungjawaban Korporasi Dalam Tindak Pidana Korupsi Pengadaan Barang Dan Jasa Pemerintah (Suatu Penelitian di Wilayah Hukum Pengadilan Tipikor Banda Aceh), Legitimasi, Vol. VII No. 1, Januari-Juni 2018, page.67-90 
only regulates criminal liability for one corporation but can also ensnare corporate groups, corporations in mergers, consolidations, separations, and also in the case of corporations being dissolved and still subject to criminal charges against the corporation. We can see the responsibility of corporations in criminal acts of corruption in the formulation of article 20 of the law on the eradication of corruption.

\section{BIBLIOGRAPHY}

\section{Books:}

Barda Nawawi Arief, 2003, Kapita Selekta Hukum Pidana, Citra Aditya Bakti, Bandung;

Dwidja Priyatno, 2004, Kebijakan Legislasi Tentang Sistem Pertanggungjawaban Pidana Korporasi di Indonesia, CV Utomo, Bandung;

Ermansjah Djaja, 2010, Meredesain Peradilan Tindak Pidana Korupsi (Implikasi Putusan Mahkamah Konstitusi Nomor 012-016-019/PPU-IV/2006, Sinar Gravika, Jakarta;

Hamzah Hatrick, 1996, Asas Pertanggungjawaban Korporasi Dalam Hukum Pidana Indonesia (strictliability dan vicarious liability), Raja Grafindo Persada, Jakarta;

Hasbullah F.Sjawie, 2015, Pertanggungjawaban Pidana Korporasi Pada Tindak Pidana Korupsi, Prenada Media Group, Jakarta;

Marwan Effendy, 2010, Pemberantasan Korupsi dan Good Governance, PT. Timpani Publishing, Jakarta;

Muladi dan Dwidja Priyatno, 2010, Pertanggungjawaban Pidana Korporasi, Kencana Prenada Media Group, Jakarta;

Peter Mahmud Marzuki, 2014, Penelitian Hukum, Kencana, Jakarta;

Remy Sutan Sjahdeini, 2017, Ajaran Pemidanaan: Tindak Pidana Korporasi dan Seluk- beluknya, PT. fajar Interpramata, Jakarta;

Ronny Hanitijo Soemitro, 1985, Metode Penelitian Prosedur Dan Strategi, Sinar Pagi, Jakarta;

Widyo Pramono, 2013, Pertanggungjawaban Pidana Korporasi Hak Cipta, PT Alumni, Bandung;

\section{Journal:}

Bambang Tri Bawono, The Strategy For Handling Corruption's Criminal Action Relationship To Saving Of State Financial Losses, Jurnal Pembaharuan Hukum, Vol 7, No 3, December 2020;

Ibsaini \& Mahdi Syahbandir, Pertanggungjawaban Korporasi Dalam Tindak Pidana Korupsi Pengadaan Barang Dan Jasa Pemerintah (Suatu 
Penelitian di Wilayah Hukum Pengadilan Tipikor Banda Aceh), Legitimasi, Vol. VII No. 1, Januari-Juni 2018;

Mustaghfirin, Irwanto Efendi, Tinjauan Yuridis Terhadap Implementasi Pidana Korupsi Dalam Upaya Mengembalikan Kerugian Keuangan Negara, Jurnal Pembaharuan Hukum, Volume 2 No. 1 Januari-April 2015;

Rully Trie Prasetyo, Umar Ma'ruf, Anis Mashdurohatun, Tindak Pidana Korporasi Dalam Perspektif Kebijakan Formulasi Hukum Pidana, Jurnal Hukum Khaira Ummah, Vol. 12. No. 4 Desember 2017;

Sri Endah Wahyuningsih Urgensi Pembaharuan Hukum Pidana Materiel Indonesia Berdasarkan Nilai-Nilai Ketuhanan Yang Maha Esa, Jurnal Pembaharuan Hukum, Vol I No.1 Januari-April 2014;

Suratno, Perlindungan Hukum Saksi Dan Korban Sebagai Whistleblower Dan Justice Collaborators Pada Pengungkapan Kasus Korupsi Berbasis Nilai Keadilan, Jurnal Pembaharuan Hukum, Volume 4 No. 1 JanuariApril 2017;

Taun, Pertanggungjawaban Pidana Korporasi Dalam Tindak Pidana Ketenagakerjaan, Jurnal IUS, Vol VI, No 2 Agustus 2018; 